\title{
MUNICIPAL BONDS USED BY POLISH RURAL MUNICIPALITIES AS AN EXAMPLE OF EXTERNAL FINANCING FOR INVESTMENTS
}

\author{
Barbara HADRYJAŃSKA \\ Uniwersytet Przyrodniczy w Poznaniu; hadryjanska@up.poznan.pl, ORCID: 0000-0003-2618-1092
}

Purpose: The main purpose of this paper was to show extra-budgetary sources of financing for municipal investments, with particular focus on municipal bonds which prove to be highly advantageous compared to loans or credits. When it comes to investment risks, the legal public status of local government units makes municipal bonds one of the lowest-risk securities.

Design/methodology/approach: The study was carried out in 2017. The basic research tool was a survey questionnaire administered to 606 rural municipalities from the Rural Municipalities Association. 132 surveys were sent back by rural municipalities located across all voivodeships (the response rate was ca. $22 \%$ ).

Findings: It follows from the study that the municipalities use credits, loans and Union grants as the basic source of extra-budgetary financing. Over $60 \%$ of municipalities surveyed do not issue municipal bonds because they lack the relevant knowledge and are concerned over excessive debt. This seems to be primarily caused by the municipal authorities' cautiousness and reluctance to rely on instruments they poorly know.

Research limitations/implications: (if applicable) If research is reported on in the paper this section must be completed and should include suggestions for future research and any identified limitations in the research process.

Practical implications: This research is in line with the proposition of the Rural Municipalities Association to establish the National Rural Development Fund whose operational instruments could include municipal bonds.

Originality/value The paper is addressed to local government units. The paper shows the true reasons why rural municipalities were not interested in issuing and selling municipal bonds.

Keywords: rural municipality, municipal investments, municipal bonds.

Category of the paper: research paper. 


\section{Introduction}

In line with the self-government concept provided for in Article 3 of the European Charter of Local Self-Government, a three-level local government organization (voivodeship, district and municipality) was put in place in Poland (European Charter of Local Self-Government, 1994). In the exercise of their public authority, local government units perform statutory public tasks on their own behalf and under their own responsibility. This means tasks other than those falling under the competence of other public authorities, as provided for in the Constitution or relevant acts. To emphasize their independence, local government are endowed with legal personality and a range of property rights (Walczak, Kowalczyk, 2010).

Decentralization processes are reflected in a number of ways, including the growing importance of local government which today's democratic states consider to be a system that makes public tasks management more efficient. Local government units (LGUs) are much more efficient in their management efforts than other structures of the public finance system (Dylewski et al., 2014). In Poland, decentralization is guaranteed in the Constitution which provides that local self-government is the decentralization formula for public authority (Constitution, Article 16.1).

Local government finance is part of the public finance system which includes processes related to the collection, distribution and expenditure of public funds based on legal regulations, financing of the budget deficit and servicing public debt. Financial autonomy is considered as the local government's right to hold enough funds to carry out its tasks, and the commitment of state authorities to provide these funds. It must be combined with an adequate structure of LGU funding sources which should primarily consist of own incomes (Bitner et al., 2013).

One of the basic tasks of LGUs is to address the needs reported by local communities. To do this, they need financial resources which are their budgetary incomes recorded as own incomes, targeted grants and subsidies. To meet all needs of the local population, investment projects must be implemented which are decisive for the LGU's development level. These projects require additional funding which may be loans, credits, resources allocated in the European Union budget, or income from their own securities.

Therefore, the main purpose of this paper is to show extra-budgetary funding methods for municipal investments, with particular emphasis on municipal bonds. Public funds deriving from the issue of bonds are repayable funds; hence, they make a temporary contribution to the local government budget and must be returned once the deadline expires. Incomes derived from the sale of municipal bonds are one of the ways to finance the LGU's budget deficit, and affect the evolution of the local government's debt. However, debt instruments, including municipal bonds, have an effect on local development because they boost the potential for investments which otherwise could not be implemented. 


\section{Using debt instruments to finance the tasks of local government units}

Local government is part of national structures, and therefore when making the decision to delegate a defined scope of public tasks to local government units, central authorities strongly believe this will improve the functioning of the state as a whole. In turn, when it comes to social aspects, it is important to have confidence that the participation of residents in the conduct of public affairs within the self-government community guarantees they have an effective impact on its functioning and development (Kowalczyk, 2017).

One of the basic functions of local government is to empower the local and regional community. This is manifested by their separation as an autonomous unit of public authority and administration. In particular, this process involves establishing an effective system for addressing social needs, and securing public confidence in, and acceptance of, actions taken by local government bodies as a condition for the effectiveness of these actions (Jastrzębska, 2012).

Local government units perform their tasks to meet the needs of the local communities by providing them with public goods and services. Also, these tasks relate to the maintenance and development of the local infrastructure which contributes to economic goals and provides a framework for the delivery of municipal, educational, cultural, social and medical services (Sochacka-Krysiak, 2013).

As a public body which is closest to the citizen, the local government has the best knowledge of the needs at local or regional level.

As provided for in Article 2 of the Municipal Government Act, the municipality is endowed with legal personality, performs public tasks on its own behalf and under its own responsibility, and its autonomy is judicially protected. Municipal self-government shall have the authority to handle local public cases which are statutorily included in its scope of activity, and to deal with tasks and competences which are not statutorily delegated to any authority and fall within the scope of local tasks and competences of the local government. The public nature of municipal activities is determined by their purpose which is to meet the collective needs of the local government community rather than handle private matters of individual interest to natural or legal persons (Czuryk, 2015).

Tasks of the local government are classed as own and delegated tasks depending on how they are transferred to LGUs by the central administration. Own tasks mean those entrusted to particular local government units as per the decentralization principle. LGUs may perform own tasks autonomously or on their own behalf (Walczak, Kowalczyk, 2010). Own tasks are those which are local in nature and are financed by the municipality who acts on a relatively autonomous basis on its own behalf (Fleszer, 2011). Own tasks are related to technical and social infrastructure, public order and security, spatial order and ecology (Pająk, 2011). Own tasks are in turn divided into mandatory or optional tasks, the latter being performed on 
the own initiative of local government units (Maśloch, Sierak, 2013). Mandatory tasks are allocated to municipalities based on legal regulations and are therefore commonplace. Optional tasks are considered to be all tasks which are not legally mandatory and can thus be performed in some municipalities only. The optional nature of municipal tasks is determined under an agreement between the parties, or by the willingness of the municipality who commits to perform additional tasks (Kozuń-Cieślak, 2008). Own tasks performed by municipalities are detailed in Article 7.1 of the Municipal Government Act.

Delegated tasks are performed by local government authorities if two conditions are met concurrently: the tasks are provided for in the Act; and result from reasonable needs of the state (Czuryk, 2015). Delegated tasks are allocated to municipalities under the applicable law. These are tasks related to state administration (e.g. preparing, organizing and conducting a municipal census; granting and disbursing targeted subsidies to cover expenses related to a natural or environmental disaster) and tasks related to organizing the preparation and conducting general elections and referenda. The performance of delegated tasks is financed by the delegating body (Ofiarski, 2010).

In addition to own and delegated tasks, there are also conferred tasks defined as tasks transferred to municipalities under agreements or arrangements between local government units or between a local government unit and central administration. The scope and financing methods of conferred tasks are provided for in the relevant agreements whose purpose is the delivery of municipal services relating to: water and sewage management, education, economic projects, social welfare, culture, tourism etc. (Zioło, 2016).

Financial management at LGU level includes collecting incomes and revenues and incurring expenses and expenditure. The variability of cash flows makes the above a dynamic process (Bitner et al., 2013).

Pursuant to the Act on Incomes of Local Government Units of November 2003 (Journal of Laws [Dz.U.] of 2003, No. 203, item 1966), incomes are divided into own incomes, general subsidies, targeted grants from the state budget, foreign funding, non-refundable funds and other funds.

Own incomes are collected from sources located within the operating area of the local government concerned, and are made available in the full amount to the local government for an indefinite period by operation of law (Walczak, Kowalczyk, 2010). They primarily include: government levies, i.e. taxes, local fees, shares in taxes and fees, and income derived from local government property, income from the local government's economic activity and capital revenue. Government levies contribute ca. 38\% (including 16.9\% from the share in central taxes) to municipal income (Kornberger-Sokołowska, Zdanukiewicz, Cieślak, 2012). In 2014, the share of LGUs' own income in their total income mix was 50.7\% (Gliniecka, Drywa, Juchniewicz, Sowiński, 2016). 
However, own incomes have the largest share in the income mix of Polish municipalities (44.1\%), compared to $25.8 \%$ for subsidies and $30.1 \%$ for grants (2016 report on implementation of the state budget).

Municipalities enjoy the greatest independence from the central budget. They have the most diversified system of incomes and the largest share in state taxes. Most local taxes and fees are paid directly to the bank account of the municipality concerned (Piasecki, 2009).

A general subsidy is the source of funding for local government tasks related to education, and enables financial support for weaker local government units. It is a general income and, in the case of municipalities, consists of the education subsidy, the compensating subsidy and the balancing subsidy (Ziółkowska, 2012).

Optional sources of municipal income include targeted grants from the state budget, allocated to such responsibilities as state administration tasks and other tasks provided for in relevant acts, tasks carried out by local government units under arrangements entered into with central administration authorities, and financing or co-financing own tasks (Dolnicki, 2009).

An important source of municipal income - and the one under the greatest control by municipal authorities - may be the income derived from property and property rights. Control is mostly reflected by the ability to set the types and amounts of these incomes. Municipal property is separate from and not related to Treasury or to property of other local government units. Therefore, the municipality may decide itself on how to use and allocate its property. Municipal income from the management of real estate owned by it can primarily include proceeds from real estate trading, i.e. proceeds derived from the sale, exchange, surrender, lease or letting of property (under the perpetual usufruct scheme or otherwise) or handing it over for perpetual management (Dolnicki, 2009).

Foreign funds are a specific type of municipal budgetary income. In Poland, these are mostly European Union funds delivered under operating programs financed by Structural Funds and the Cohesion Fund (Miszczuk, 2009).

In the performance of their tasks, municipalities may rely on other refundable funds, i.e. loans, credits and issuance and sale of securities. As an important part of municipal operations, loans and credits are the most frequently used source of funding for the municipalities because they represent a convenient way of collecting necessary resources for investments (Owsiak, Maj-Waśniowska, 2009). Being generally available and relatively highly flexible, credit is the best known method of accessing capital for municipal investments. This can be also caused by the policy followed by banks - one of the key partner groups for LGUs - which consists in promoting credits as they represent a good source of income for banking institutions (Maśloch, Sierak, 2013).

Debt instruments used by municipalities to finance their investments are municipal bonds.

In 2000, the Bond Act was amended to enable the issuance of bonds by local government units (Bond Act of June 29, 1995). Article 4.1 of the new Act, which has been in place since 2015 , defines bonds as serial securities issued by a party who declares to be the debtor of the 
bond owner (bondholder) and undertakes to provide a specific performance to him/her (Bond Act of January 15, 2015).

Public funds deriving from the issue of bonds are repayable funds; hence, they make a temporary contribution to LGUs' budgets and must be returned once the deadline expires. Incomes derived from the sale of municipal bonds are one of the ways to finance the local government unit's budget deficit, and affect the evolution of the local government's debt. Note however that debt instruments, including municipal bonds, have a favorable effect on local and regional development. High levels of debt do not necessarily mean an adverse event. Often, debt is the result of the investment strategy adopted by municipal authorities (Hanusz et al., 2015).

Municipal bonds may be issued to cover a temporary deficit, provided they are issued and redeemed during the same year. Also, municipal bonds may be issued to finance a planned budgetary deficit of a local government unit or to repay earlier debt securities, loans and credits. LGUs may also incur debt by issuing bonds to provide early financing for measures supported by the European Union budget (Hanusz et al., 2015).

The investors perceive municipal bonds as low-risk securities (similarly to government bonds) because an LGU, as the issuer (Jastrzębska, 2012):

- cannot go bankrupt (in accordance with legal regulation, it cannot be declared insolvent),

- owns fixed assets of considerable value which allow to provide the bondholders with a collateral,

- enjoys legally guaranteed economic independence which results from a broad and diverse revenue base,

- makes financial management information public to ensure transparency of decisionmaking, inspection and bureaucratic routines (Article 11 of the Public Finance Act).

Other advantages of issuing municipal bonds are as follows: conditions governing the issuance are transparent; funds derived from the issuance are available to the issuer straight away; the issuer may define the redemption schedule; the creditors are dispersed which places the borrower in a stronger position; the promotional effect; and if the LGU opts for publicly traded bonds: the cost of capital is low; the LGU may offer benefits in kind; and no collaterals are required (Maśloch, Sierak, 2013).

The advantage of bonds over other forms of municipal investment financing is their flexibility, relatively long maturities (period of debt financing), and a less complicated (a simplified) procedure. It is also important to note that when issuing bonds, the municipalities also trigger a promotional effect and strengthen their cooperation with financial institutions who, acting as counselors, prepare the market introduction of bonds (Filipiak, 2016). 
The disadvantages of municipal bonds include (Maśloch, Sierak, 2013):

- a long and complex issuance procedure,

— vulnerability to fluctuations of market interest rates,

- difficulties in conducting the issuance process in poorly developed financial markets,

- high costs of and strict formal conditions for entering the public market (rating, counseling, costs of listing),

- bond redemption as a one-time process; the need to secure a large amount of funds at a defined redemption date,

- problems involved in establishing a collateral (if any) or in an early redemption of bonds issued.

Municipal bonds have several functions which are strongly interrelated and impact each other while also having an effect on whether or not it is advisable to buy the bonds. The key functions of municipal bonds include: being a deposit, a loan, a form of payment, currency, guarantee, promotion, activation and refinancing, a privatization method, a way to attract capital, and a driver of development (Jastrzębska, 2012).

Municipal bonds may be classed by various criteria, including the one provided in the Bonds Act which distinguishes between registered and bearer bonds. That classification is based on the method of transferring property rights granted under particular types of bonds. A restricted right to sell bonds can only be applicable to registered bonds.

When it comes to the form of bonds, the provisions of the Act allow for trading of both physical and dematerialized bonds. Another classification criterion is the type of liability incurred by the issuer. From that perspective, the Act makes a distinction between monetary, non-monetary and mixed bonds. Also, bonds may be grouped by redemption date as short-term (with a maturity of one year), medium-term (with a maturity of one to five years) and long-term bonds (with a maturity of more than five years).

When taking the principles of charging interest into consideration, a distinction can be made between fixed interest rate bonds, variable interest rate bonds, indexed bonds (with an interest rate determined based on the price index, currency exchange rate or market value of defined goods) and zero-coupon bonds (the bondholders' income is the discount, i.e. the difference between the price paid and the face value of the bond paid at redemption).

Depending on the place of issuance and currency of municipal bonds, bonds can be grouped into domestic bonds, foreign bonds and Eurobonds. In turn, when it comes to the redemption procedure, a distinction is made between a one-off repayment, a sequential repayment and an early repayment option (Hanusz et al., 2015).

Using the purpose of issuance as a criterion, two groups of bonds (active and passive) can be identified. Active bonds are issued to access new funds for purposes specified by the issuer in the terms and conditions of issuance, whereas the goal of passive bonds is to finance the existing liabilities. 
When it comes to the form of the issuing process, bonds may be grouped as publicly offered bonds (listed in the Warsaw Stock Exchange) and privately offered bonds (in the brokers' market).

Also, based on the method for introducing the bonds on the market, a distinction can be made between bonds issued in series and tranches. The former represent property rights divided into a definite number of equal units. In turn, the latter enable the distribution of incomes derived from the issuance of debt securities.

Also, there are general and income bonds serviced with specific sources of income (Jastrzębska, 2012).

The liberalization of formal requirements for the public offering of LGU bonds could provide momentum for the development of this type of bonds in Poland through a reduction in issuance costs. Furthermore, the requirement for LGUs to comply with obligations applicable to trading in securities is a guarantee of a risk-free transaction for bondholders (Chojecka et al., 2009).

Even though the municipal bond market has been growing stronger each year, bank credit continues to be the most popular method of incurring debt for the LGUs (with a share of over $80 \%$ in total liabilities). It follows from the above that the quantitative development of that market in Poland cannot be deemed satisfactory. Although the market grows each year, the growth rate of market value is low. While the number of issuers keeps growing, only $15 \%$ of LGUs became issuers.

Private offering of bonds intended for a defined buyer is the prevailing option. Neither new securities nor securities modified with extended options enter the market. All issuance processes are covered by bank guarantees; also, banks are the largest group of buyers of municipal bonds. Interest periods are usually one year, with six-month coupons being less frequent. Most bonds bear a variable interest rate; all bonds issued are short- and medium-term liabilities; a maturity of 3 to 8 years predominates. Extremely small issuances predominate, with a value of up to PLN 10 million. In only few cases, the unit value of bonds is small enough to be intended for natural persons, i.e. the local community (Kozuń-Cieślak, 2010).

In 2012, the ratio of liabilities incurred by LGUs on account of securities to total debt instruments, i.e. loans, credits and payable liabilities, was only $8.5 \%$ (Local government units' liabilities by debt instrument in 2010 to 2Q 2012).

\section{Materials and method used in empirical research}

The empirical study was carried out in $1 \mathrm{H} 2017$. The basic research tool was a survey questionnaire. It included 10 questions and was administered to 606 rural municipalities from the Rural Municipalities Association (RMA). The questions were about both general municipal 
bonds and income bonds. The questionnaire was e-mailed with an active participation from RMA management.

132 surveys were sent back by rural municipalities located across all voivodeships (the response rate was ca. 22\%). The greatest number of replies was from the Mazowieckie voivodeship (19) and the smallest from the Lubuskie, Opolskie and Podkarpackie voivodeships (2 surveys each). Questionnaires were also sent back from the Wielkopolskie and Łódzkie voivodeships (17 replies each), the Dolnośląskie and Kujawsko-Pomorskie voivodeship (13 replies each), the Lubelskie voivodeship (9 replies), the Małopolskie voivodeship (8 replies), the Podlaskie and Śląskie voivodeship (7 replies each), the Świętokrzyskie voivodeship (6 replies), the Pomorskie voivodeship (4 replies), and the Warmińsko-Mazurskie and Zachodniopomorskie voivodeship (3 replies).

\section{Results and discussion}

The vast majority of Polish rural municipalities (over 90\%) use Union subsidies, credits and loans to finance local government investments (Fig. 1). 38 municipalities opted for municipal bonds, and only 2 municipalities issued income bonds. Thus, rural municipalities are not interested in income bonds as a source of financing for potential investments (as many as $98 \%$ of respondents did not use that source). The main reasons for this (as cited by $30 \%$ of municipalities) are the lack of information on the availability of that financial instrument and the concern over excessive municipal debt. $15 \%$ of respondents stated they did not rely on income bonds due to complicated procedure and difficulties in finding buyers for this type of debt securities. Legal uncertainties within the Public Finance Act, the lack of specialized staff and large organizational costs involved the issuance of income bonds are important reasons why the municipalities do not opt for this type of instruments. Rural municipalities did not use income bonds because they did not needed to do so and lacked investments which in the future would generate enough income to redeem the bonds. Also, several municipalities claim that current solutions are insufficient, and that they can access investment funds on more favorable terms. For instance, a credit can be obtained in a faster and less expensive way, based on known procedures.

$40 \%$ of rural municipalities who issued bonds did so only once; $31 \%$ did so $2-3$ times; and $29 \%$ did so more than 3 times. 


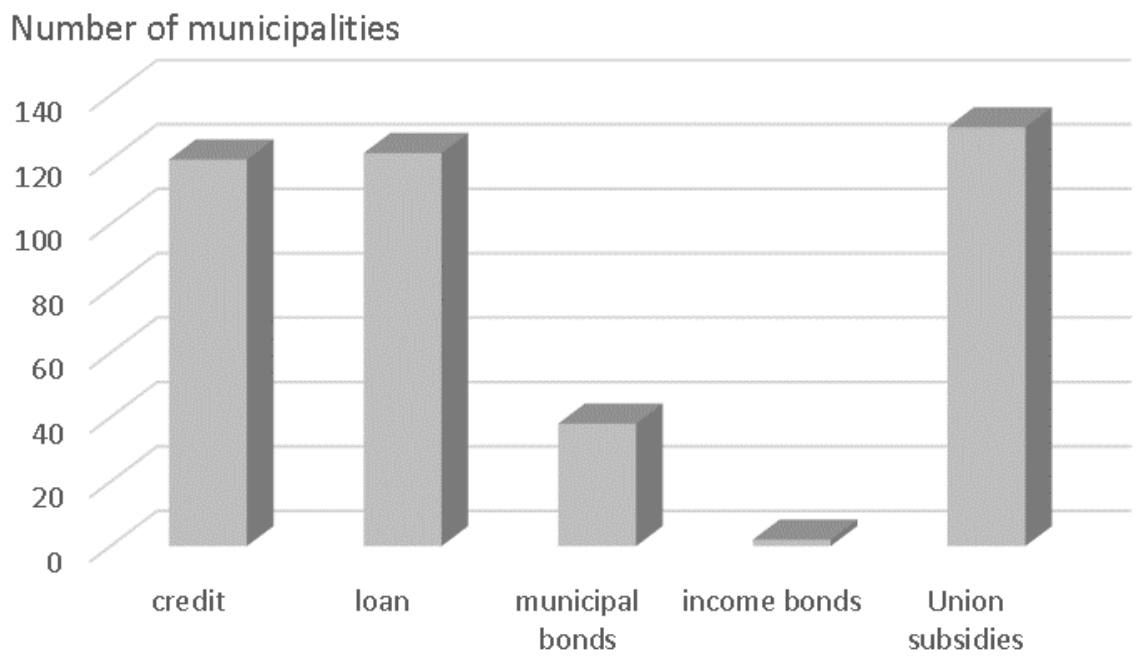

Figure 1. Using external sources to finance investments of Polish rural municipalities. Source: own study.

For most rural municipalities, the motive behind using municipal bonds was the ability to implement investments and the low costs of bond issuance (nearly 70\%), as well as the opportunity to access funds without applying the Public Procurement Act (50\% of interviewees) (Fig. 2). Nearly $40 \%$ of municipalities opted for that source of financing to gain new knowledge and experience in using this type of financial instruments. Ca. $30 \%$ of rural municipalities stated that the low value of interest coupons was important for them, and that the bonds allowed them to collect enough capital to access Union subsidies. 


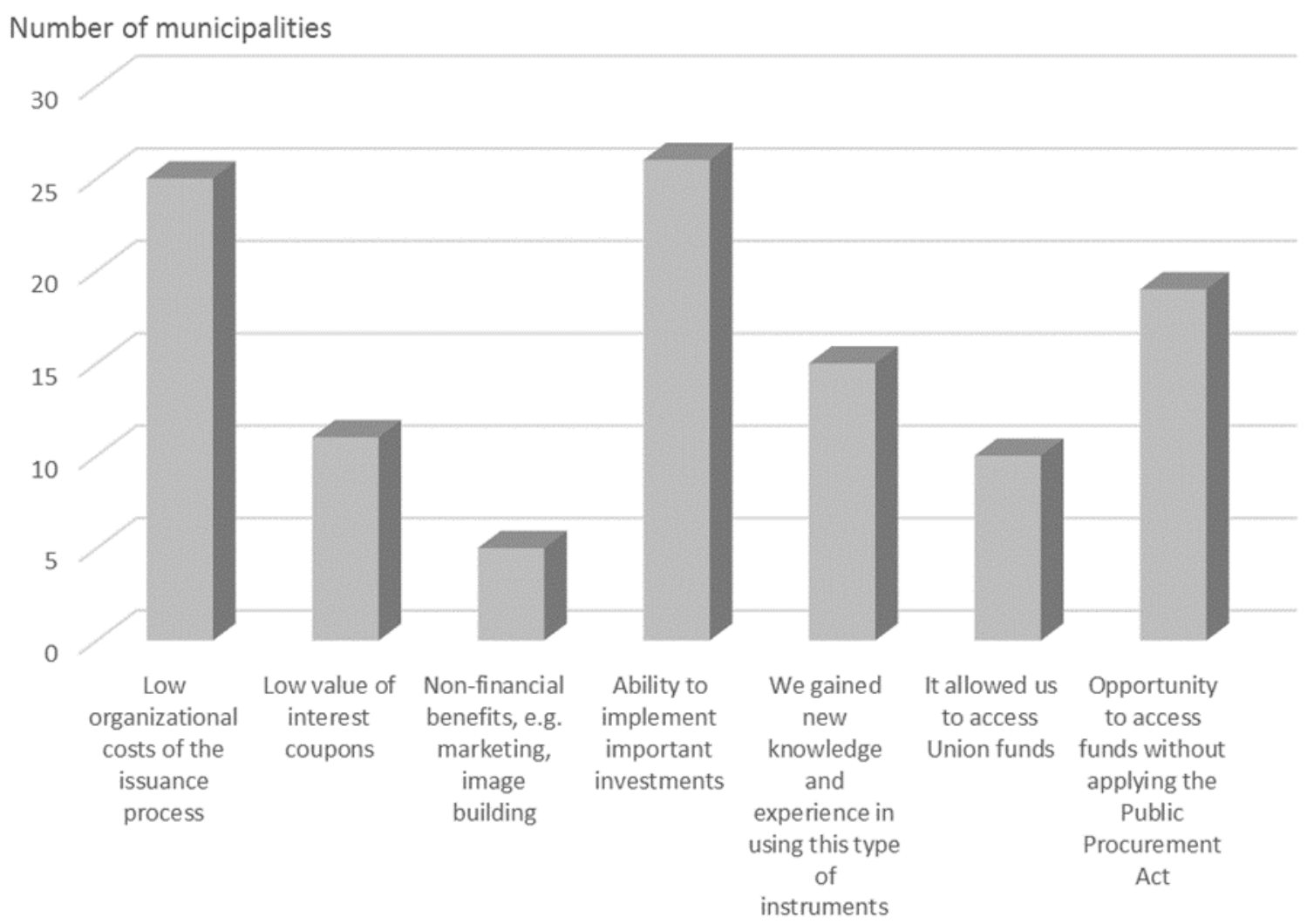

Figure 2. Reasons behind using municipal bonds in rural municipalities. Source: own study.

In rural municipalities covered by the survey, funds collected through bond issuance were mainly allocated to road infrastructure (over 60\%) and to environmental protection and education (55\%) (Figure 3). Less than half of respondents used the funds to support physical culture whereas only a small minority allocated the resources to healthcare and municipal housing.

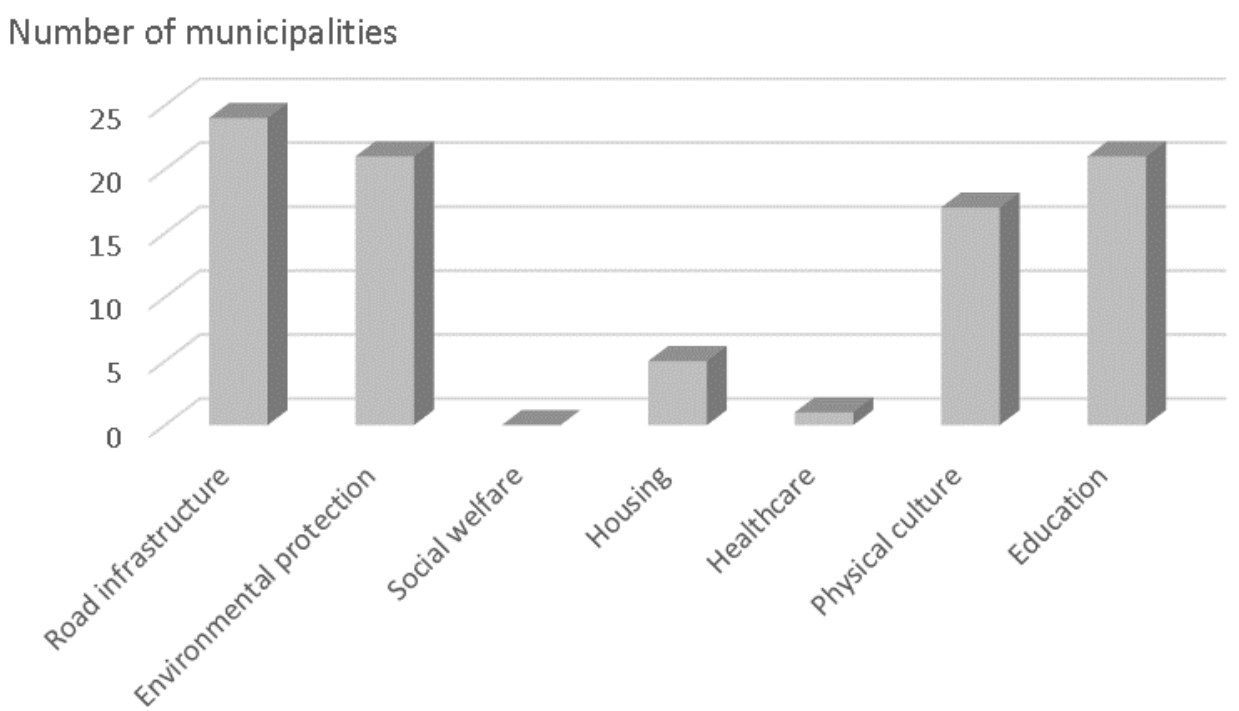

Figure 3. Allocation of funds derived from the issuance of municipal bonds. Source: own study. 
Municipalities who did not use municipal bonds as an external financing instrument indicated their concern over excessive indebtedness to be the main reason for their reluctance (84\%) (Figure 4). More than $40 \%$ of rural municipalities believe the bond issuance procedure to be complicated; indicate the high organizational costs involved in the issuance to be an important factor; and find it difficult to search for bond buyers. Over $30 \%$ of municipalities declared not to have issued municipal bonds because they lacked information on the availability thereof and due to high interest costs of bonds.

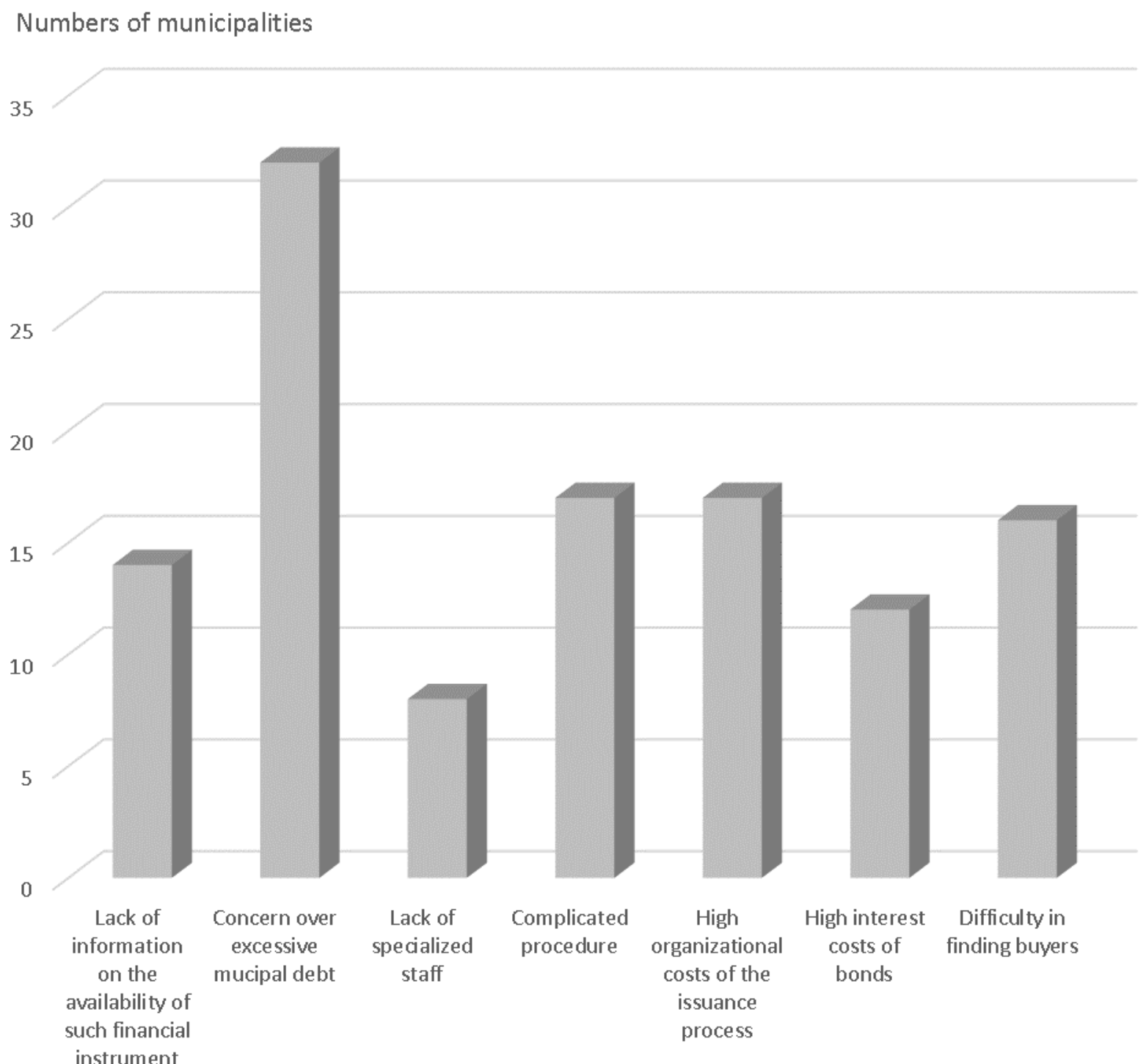

Figure 4. Reasons why rural municipalities do not use municipal bonds. Source: own study. 


\section{Summary}

As the basic local government unit, municipalities carry out current tasks related to addressing the population's needs. To do this, they need financial resources which are largely derived from government levies and central subsidies and grants. However, in order to develop, they need to invest. Usually, the required funds are derived from credits, loans or securities issued.

To generate the capital they need to invest, the municipalities can issue municipal bonds as an alternative to loans and credits. Unfortunately, rural municipalities do not widely rely on such instruments: over several decades of availability, municipal bonds have been issued by less than $30 \%$ of municipalities surveyed.

Rural municipalities who did issue bonds were guided by a greater investment potential and low organizational costs of the issuance process. Funds collected that way were primarily allocated to the road infrastructure, environmental protection and education.

Based on the empirical study, the authors wanted to discover the true reasons why rural municipalities were not interested in issuing and selling municipal bonds. The survey feedback suggests that the basic sources of extra-budgetary financing for the municipalities are Union subsidies and credits and loans, which are a known and proven method for implementing municipal investments. The municipalities do not issue municipal bonds because they lack the relevant knowledge and are concerned over excessive debt. This seems to be primarily caused by the municipal authorities' cautiousness and reluctance to rely on instruments they poorly know. The objective of a broader research is to formulate debt instruments which make the investment process easier and boost the investment potential, especially for small rural municipalities. This is of particular importance in the light of enormous development needs, limited financing capabilities of rural municipalities and the prospect of non-refundable Union aid. This research is in line with the proposition of the Rural Municipalities Association to establish the National Rural Development Fund whose operational instruments could include municipal bonds.

\section{References}

1. Bitner, M., Cichocki, K.S., and Siera, J. (2013). Standardy zarzadzania dtugiem na szczeblu lokalnym i regionalnym oraz ich wptyw na finansowanie infrastruktury. Warszawa: Polska Akademia Nauk Instytut Badań Systemowych.

2. Chojecka, I., Giza, D., Grybionko, K., Ostrowski, J., Stępniewski, M., Śliwiński, P. (2009). Obligacje komunalne. Zagadnienia prawne, finansowe, praktyczne. Warszawa: Twigger. 
3. Czuryk, M. (2015). Samorząd terytorialny w Rzeczypospolitej Polskiej. In: M. Czuryk, M. Karpiuk, and J. Kostrubiec (Eds.), Samorzad terytorialny $w$ państwach Unii Europejskiej (pp. 390-392). Warszawa: Akademia Obrony Narodowej.

4. Dolnicki, B. (2009). Samorzad terytorialny. Warszawa: Wolters Kluwer.

5. Dylewski, M., Filipiak, B., Gorzałczyńska-Koczkodaj, M., and Zioło, M. (2014). Finanse publiczne. Aspekty teoretyczne i praktyczne. Warszawa: Wydawnictwo C.H. Beck.

6. Europejska Karta Samorządu Terytorialnego, sporządzona w Strasburgu dnia 15 października 1985 r. (DzU z 1994 r. nr 124, poz. 607).

7. Filipiak, B.Z. (2016). Produkty strukturyzowane jako szczególny rodzaj produktów finansujących zadania inwestycyjne JST. In: B.Z. Filipiak, and M. Zioło (Eds.), Wspótpraca jednostek samorzadu terytorialnego z instytucjami finansowymi. Uwarunkowania-procesydecyzje (p. 158). Warszawa: Difin.

8. Fleszer, D. (2011). Samorząd terytorialny i jego zadania w świetle uregulowań prawnych rozbieżności interpretacyjne. In: M. Stefański, and H. Stępień (Eds.), Gospodarka i finanse gmin w Polsce. Wybrane zagadnienia (p. 53). Włocławek: Wyższa Szkoła HumanistycznoEkonomiczna we Włocławku.

9. Hanusz, A., Niezgoda, A., Czerski, P., Musiał, M., and Szczęśniak, P. (2015). Źródła finansowania samorzadu terytorialnego. Warszawa: Wolters Kluwer.

10. Jastrzębska, M. (2012). Finanse jednostek samorządu terytorialnego. Warszawa: Wolters Kluwer.

11. Jastrzębska, M. (2016). Decentralizacja finansów publicznych w Polsce i finanse samorządowe w systemie finansów publicznych. In: J. Gliniecka, A. Drywa, E. Juchniewicz, and T. Sowiński (Eds.), Finansowanie jednostek samorzadu terytorialnego. Problemy praktyczne (p. 46). Warszawa: CeDeWu.

12. Konstytucja Rzeczypospolitej Polskiej z 2 kwietnia 1997 RP, art. 16, ust. 1, art. 164, ust. 1.

13. Kornberger-Sokołowska, E., Zdanukiewicz, J., and Cieślak, R. (2012). Jednostki samorządu terytorialnego jako beneficjenci środków europejskich. Warszawa: Wolters Kluwer.

14. Kowalczyk, M. (2017). Podstawy analizy ekonomiczno-finansowej w jednostkach samorzadu terytorialnego. Warszawa: Difin.

15. Kozuń-Cieślak, G. (2010). Ocena rozwoju i dysfunkcje rynku obligacji komunalnych w Polsce. In: L. Patrzałek (Ed.), Gospodarka finansowa jednostki samorzadu terytorialnego. Zagadnienia wybrane (pp. 149-150). Poznań: Wydawnictwo Wyższej Szkoły Bankowej.

16. Miszczuk, M. (2009). System podatków i opłat samorządowych w Polsce. Warszawa: Wydawnictwo C.H. Beck.

17. Ofiarski, Z. (2010). Prawo finansowe. Warszawa: Wydawnictwo C.H. Beck.

18. Owsiak, K., and Maj-Waśniowska K. (2009). Obligacje przychodowe jako źródło finansowania zadań publicznych przez jednostki samorządu terytorialnego w Polsce. 
In: L. Patrzałek (Ed.), Finanse lokalne. Wybrane zagadnienia (p. 177). Poznań: Wydawnictwo Wyższej Szkoły Bankowej.

19. Pająk, K. (2011). Samorząd terytorialny i jego wewnętrzna transformacja. Toruń: Wydawnictwo Adam Marszałek.

20. Piasecki, A.K. (2009). Samorząd terytorialny i wspólnoty lokalne. Warszawa: PWN.

21. Sierak, J. (2013). Gospodarka finansowa jednostek samorządu terytorialnego. In: G. Maśloch, and J. Sierak (Eds.), Gospodarka i finanse samorzadu terytorialnego (pp. 191, 195-196). Warszawa: Oficyna Wydawnicza. Szkoła Główna Handlowa.

22. Sochacka-Krysiak, H. (2013). Ustrój i organizacja samorządu terytorialnego. In: G. Maśloch, and J. Sierak (Eds.), Gospodarka i finanse samorzadu terytorialnego (pp. 29-30). Warszawa: Oficyna Wydawnicza. Szkoła Główna Handlowa.

23. Sprawozdanie z wykonania budżetów gmin za grudzień 2016, http://www.mf.gov.pl/ ministerstwo-finansow/dzialalnosc/finanse-publiczne/budzety-jednostek-samorzaduterytorialnego/sprawozdania-budzetowe, 17.09.2017.

24. Ustawa z 8 marca 1990 r. o samorządzie gminnym, Dz.U. nr 16, poz. 1591 (Obwieszczenie Marszałka Sejmu Rzeczypospolitej Polskiej z dnia 17 marca 2016 r. w sprawie ogłoszenia jednolitego tekstu o samorządzie gminnym, Dz.U. z 2016 r., poz. 446).

25. Ustawa z dnia 13 listopada 2003 r. o dochodach jednostek samorządu terytorialnego, Dz.U. z 2003 r., nr. 203, poz. 1966 (Obwieszczenie Marszałka Sejmu Rzeczypospolitej Polskiej z dnia 18 marca 2015 r. w sprawie ogłoszenia jednolitego tekstu o samorządzie gminnym, Dz.U. z 2015 r., poz. 513).

26. Ustawa z dnia 27 sierpnia 2009 r. o finansach publicznych, Dz.U. 2009 nr 157, poz. 1240 (Obwieszczenie Marszałka Sejmu Rzeczypospolitej Polskiej z dnia 14 października 2016 r. w sprawie ogłoszenia jednolitego tekstu ustawy o finansach publicznych, Dz.U. 2016 poz. 1870).

27. Ustawa z dnia 29 czerwca 1995 r. o obligacjach, Dz.U. z 2001 r., Nr 120, poz. 1300 z późn. zm.

28. Walczak, M., and Kowalczyk, M. (2010). Rachunkowość i budżetowanie w zarzadzaniu finansami gminy. Warszawa: Difin.

29. Zioło, M. (2016). Specyfika funkcjonowania jednostek samorządu terytorialnego a popyt na usługi finansowe. Uwarunkowania-procesy-decyzje. In: B.Z. Filipiak, and M. Zioło (Eds.), Wspótpraca jednostek samorzadu terytorialnego z instytucjami finansowymi. Uwarunkowania-procesy-decyzje (p. 24). Warszawa: Difin.

30. Ziółkowska, W. (2012). Finanse publiczne. Teoria i zastosowanie. Poznań: Wydawnictwo Wyższej Szkoły Bankowej.

31. Zobowiąania wedlug papierów dlużnych jednostek samorządu terytorialnego wg tytułów dłużnych w latach 2010 - 2 kwartały 2012 (październik 2012) Warszawa: Ministerstwo Finansów, 3. 